* Assistant Professor, Department of Economics, Calffornia State University, Los Angeles

** Professor, Department of Agricultural Economics and Rura1 Soclology, The Ohio State University 
The Economic Performance of the Food Producing Sector in Jamaica, 1962-79: A Policy Analysis

The purpose of this paper is to analyze the performance of the domestic food producing sector in Jamaica. An evaluation of this sector's performance is warranted on several grounds. First, Jamaica stands out as a country experiencing approximately eight consecutive years of negative rates of growth for the national economy from 1972 to 1980. However the domestic food sector grew at an average annual rate of 3.21 percent over the same period. An understanding of the factors behind this growth is called for while the rest of the economy was in a downward cycle. Second, this increase in food production occurred while, at the same time, agricultural export production declined dramatically. In this respect, the agricultural sector's performance is unusual in the Latin American setting where most countries promoted agricultural exports during the 1970s largely at the expense of domestic food production. 1/ Third, the populist government of Michael Manley (1972-80) has claimed that its programs, designed to improve equity and efficiency among agricultural producers, were responsible for the resulting rapid growth of domestic foodstuffs in Jamaica in the late 1970s. This analysis is of particular importance in light of a recent work suggesting that "equity" motivated policies (i.e. 1and reform, and related rural development schemes) frequently have negative consequences for efficiency and output.2/ The degree to which the Jamaican case may or may not constitute an exception to this rule forms the basis of this article. In addressing this issue we also illustrate the misconceptions and the distortions that frequently accompany a populist food policy program. 
First, we review the overall patterns of growth of the Jamaican economy during this period and the major trends of structural change in the agricultural sector. We then present and evaluate specific policies undertaken by both the Jamaica Labor Party (JLP) administration of the 1960 's and the People's National Party (PNP) government of the 1970's. These polfcies were designed to remove perceived structural constraints that had allegedly reduced efficiency and brought about inequities among domestic food producers. Further, we document and analyze the influence of prices and price policies on the supply of domestic foodstuffs. This has not been heretofor documented and addressed directly in the Jamaican case since policymakers and researchers have generally felt that structural constraints rather than pricing disincentives conditioned the low economic rate of return to domestic food enterprises. Finally, we draw out the implications associated with the causal factors behind the increases in domestic food production in the 1970 s.

\section{Major Trends in the Jamaican Agricultural Sector}

Table 1 portrays the growth rates for selected sectors of the Jamalcan economy from 1962 to 1979. As noted above, the Jamaican economy experfenced negative real rates of growth over the decade of the $1970^{\prime} \mathrm{s}$. These data also show the sharp contrast between the negative growth of export agriculture, and positive growth of domestic food crops and livestock activities. These contrasts are further supported by data from the Jamaican agricultural census. In Table 2, it can be seen that since 1961, there has been a marked increase in the number of farmers who derive most of their income from domestic crop production. This 
shift is particularly noticeable among the smaller sized farm holdings. Large farmers, 100 acres or more, also moved out of export crop activity and into livestock and/or domestic crop enterprises. It should be noted that while farmers moved into livestock production in the 1960's, there was a decline of livestock enterprises in the 1970's.

Another important trend can be noted by examining census data on the source of princtpal livelthood for agricultural producers. It is not surprising that farming (full and part-time) provided farms with their major source of income. The data in Table 3 appear to support the hypothesis that as farm size increases, so does the share of income coming from farm enterprises. More farms rely on farm income on farms with more than 5 acres. It is of interest to note that, on the smallest size farms, there was an increase from 1968 to 1978 in the number of farms who relied more on farming for income than off-farm agricultural or non-agricultural employment. The decline in importance of this offfarm employment is due, most 1 ikely, to the sharp decline of the economy in the 1970's. However, it may also be due in part to a relative increase in the rate of return to farming, specifically domestic food production in a recessionary environment in the non-agricultural sector. Data on land distribution in Jamaica for the periods 1954, 1961, 1968, and 1978 are presented in Tables 4 and 5. As can be seen, total 1 and in the agricultural sector has declined over time, from approximately two million acres in 1954 to 1.3 million acres in 1978 (Table 5). This has been due to a decline in export production, the more rapid growth of urban employment up to 1972 , the equally rapid emigration from the island during this period and the expansion of bauxite lands onto 
former agricultural 1and. Land distribution in Jamaica is also highly concentrated. Approximately 3 percent of the farms controlled 60 to 75 percent of the total 1and in agriculture over the period 1954-1978 (Tables 4 and 5). Examination of farm-size data reveals that, while total acreage in each farm-size category has declined since 1954, the remaining land has become more concentrated into larger farm sizes while the number of farmers has grown sharply in the smallest sized class. This is the typical minifundia-latifundia bi-model distribution discovered in most Latin American settings. For example, farms 100 acres or more increased their share of total land from 48 percent in 1954 to 57 percent in 1978, while farms of less than 5 acres only increased their a rea holdings from 13 percent in 1954 to 16 percent in 1978. This shift did not improve equity in land distribution. In 1954, 69 percent of the smallest farm class held 13 percent of all land, while in 1978, 82 percent had 16 percent of all land in the agricultural sector.

Thus, we find that domestic food production increased, while export production declined. Further, most of the domestic food producers are small farmers with less than 5 acres of land relying primarily on farming as a major source of income. Moreover, land distribution has become more concentrated among a smaller number of larger farmer holdings, reducing equity within the agricultural sector. We now turn to an examination of the agricultural policles that have influenced these trends.

\section{Government Agricultural Policies}

Agricultural policies in Jamaica that have been directed at increasing output and improving equity among small domestic food 
producers have been carried out under the auspices of the Ministry of Agriculture. The primary emphasis of these policles have been to develop rural infrastructure and subsidize farm practices that will help modernize Jamaican agriculture. It was expected that this improved infrastructure and modernization would lead to increases in output and reduce Jamaica's need for food imports, which averaged 19 percent of total imports per year over the past 15 years.

Under the Jamaica Labour Party (JLP) government (during 1960-1972) three different programs were launched, each lasting 3 to 4 years. These efforts distributed subsidies and loans for such improvements in infrastructure as water tanks, farm houses, and soil conservation and operational subsidies for the use of fertilizer. Jamaican scholars have commented that funds from such programs have been misused (1.e. diverted for farm household consumption) and that these programs have done little to increase farm output. $3 /$ This point is further confirmed by examination of the limited impact of these agricultural subsidy programs among the relevant farmer population (Table 6). Assuming a total of 172,000 farms (i.e. the average number of farms below 25 hectares between the 1961 and 1968 agricultural censuses), the average percent of farmers reached came to $2-10 \%$ for the period 1964-1971, the years of the $\pi P$ government. The total annual program expenditure averaged 6 percent of domestic crop GDP. While it is true that domestic food production did increase over this period, it is difficult to assign a causal relationship to these subsidy schemes given their limited impact among producers. Comparable data do not exist to fully evaluate the reach of the Peoples National Party (PNP) subsidy programs in the 1970's. 
Subsidies for fertilizer consumption were another commonly used means to increase output and productivity. This data is presented in Table 7. Since most fertilizers in Jamaica are used for export crops, it is not surprising to note that banana and sugar cane enterprises received the majority of this subsidy. When the PNP came into power in 1972, the subsidy was only expected to be directed to farms with less than 25 acres with the subsidy equaling one third of the price. Yet the average value of the subsidy, if given across the board, would have averaged only 11 percent of the price during the JLP administration. Given the sharp bias in favor of export crops, it appears that the subsidy has done little to improve fertilizer use among domestic crop farmers. Further, it is unlikely that any administrative machinery existed that could have effectively channeled much of this subsidy to the intended small farmer target group.

\section{PNP Policies to Stimulate Domestic Food Production}

The PNP government (1972-80) was also committed to a policy of food self-sufficiency and modernization of agriculture. To help meet this policy goal, and at the same time promote a more equitable distribution of assets within the agricultural sector, a land distribution program was developed. While the maldistribution of land has been cited as an important constraint on domestic food production (and documented above in Tables 4 and 5), it was urban politicians and political groups, and not farmers or landless peasants, that pushed for this program.4/

The Land Lease Program was designed to divide idle large holdings and allow small parcels of these holdings to be leased to farmers on 
long term contracts (up to 49 years in some cases). In addition to 1 and, the government provided infrastructure investment and loans. Table 8 shows that, from 1973 to 1979, a total of 37,205 tenants were placed; 65,909 arable acres were made available for production on land lease farms and 234,785 tons of domestic foodcrops were produced on these farms. The cost of this program came to $\$ 25$ million Jamaican dollars of which $9 \mathrm{million} \mathrm{J}$. dollars were in the form of loans with only 1.6 million $\mathrm{J}$. dollars recovered in repayments. Over the period, 1973-79, Land Lease production accounted for only 8.2 percent of total output. However, in the last two years of the program, Land Lease farms increased their share of total domestic food crop output to 10.5 and 16.9 percent respectively. $5 /$ The high rate of default on these loans strongly suggests that Land Lease farmers probably felt that such loans were grants designed for their use, and not loans that needed to be repaid. Moreover, it appears that this program did not increase equity within the agricultural sector as land distribution has become more concentrated, as previously noted.

Efforts were also made by the government to establish collective food farms. From 1973 to 1976, approximately 10 million Jamaican dollars (in 1974 constant Jamaican dollars) was spent on the establishment of food farms, but output was negligible and the effort abandoned. From 1977 to 1979, Pioneer Farms replaced the food farms with similar disappointing results, but only 1 million $J$. dollars (in 1974 constant J. dollars) was spent on this effort. Another major policy to stimulate domestic food crop production was the Crop Lien Program. This was the credit scheme of the Emergency 
Production Plan (EPP) established in 1977. The EPP was designed to increase domestic foodstuff production as a substitute for growing food imports. These imports were becoming difficult to maintain in the face of a worsening balance of payments deficit in the mid 1970s. The increased output was to have come from Pioneer farms and from private farms whose production would be stimulated by the Crop Lien Credit Program. Approximately 44,000 farmers were reached over a three-year period 1977-1979, with 80 percent of the farms that were to be reached by the program, participating in the first year (Table 9). The rapid decline in the number of farmers and loans granted (columns 1 and 2) underscores the inability to financially maintain a costly program of this nature. In brief this small farmer loan program was quickly transformed into an ad-hoc income transfer program. The arrears rate on loans in this program averaged a remarkable 94 percent. $6 /$ Moreover, the impact on output was minimal. Production on farms with Crop Lien loans accounted for only 5 percent of total output. There is also some question as to whether this program could have led to any significant tncreases in agricultural output due to the existing constraints on imported inputs which would have been purchased by the loan. Further, field interviews undertaken by the authors revealed that a large part of the loans of the interviewed crop lien farmers went toward consumption 1 tems 71

\section{Research, Extension and Marketing}

In addition to developing programs to modernize agriculture, both the JLP and PNP governments tried to generate productivity increases via research. However, neither government undertook investments that would 
have promoted sustained productivity increases. This is brought out by examining the ratio of research expenditures to domestic crop GDP and livestock GDP (Table 10) and evidence on crop yields (Table 12). This is in contrast to the development schemes of limited impact discussed earlier which averaged 3 to 4 times the level of research expenditure. Extension expenditure averaged 4 to 5 times research expenditure. This finding is consistent with Boyce and Evenson, who found that less developed countries spend relatively more on extension than on research activities. $8 /$ This may be due to a belief that extension activities are a cheap way to increase agricultural output.9/ Also, extension activity is important in providing services when there is a lack of rural infrastructure. Underinvestment in research by both governments may also be due to the disincentives associated with the long gestation period needed for research breakthroughs.

Research expenditure has been low for domestic food crops and livestock by any standard. However, of equal importance is that the ifmited research findings in the past have not been transmitted to the farmer, with the exception of the Jamaican Hope and Red Poll cattle breeds. Most domestic crop research results have been cataloged in scientific jargon in a technical publication of the Ministry of Agriculture. Interviews by the authors with Ministry officials and extension agents lead one to believe these findings were not translated effectively into layman's language for extension use. Furthermore, it was discovered that some of the more important crop research results have heen trresponstbly filed away and misplaced in Ministry files.10/ 
In light of the above, technological change does not appear to have been an important factor behind the increases in domestic foodcrop output. Another major constraint frequently cited in the Jamaican context is the poor marketing system. To overcome this constraint, the JLP set up a domestic food crop marketing board called the Agricultural Marketing Corporation (AMC) in 1963. The AMC, however, has never been able to fulfill its role as a major marketer of domestic food crops. Over the past 15 years, the AMC has marketed an average of only 6 percent of total output (Table 11). Deficits amounting to several million J. dollars a year have been incurred and substantial government subsidies have been required to cover the deficit. As can be seen in Table 11 , the subsidies have totaled $\$ 32$ million $J$. dollars, approximately $1 / 3$ of the value of total food crop purchases in 1974 constant dollars. Clearly, if there is a marketing constraint, it is still in place as the AMC has not relaxed it. Currently, a project to improve the island's wholesale marketing infrastructure is being undertaken by AID and the Ministry of Agriculture. One of the main purposes of this undertaking is to improve the poor performance of all (private and public) marketing agents In Jamaica, reduce post-harvest losses and increase the marketable surplus of farms.

Government policies designed to reform and modernize domestic food production have had 1ittle impact on production. Structural constraints such as the maldistribution of land, a poor marketing system, and the lack of appropriate technology have not been overcome by government policies designed to relax these constraints. This can be further evaluated by analyzing whether increases in food output are the result of 
11

supply or demand shifts. A simple test can examine the correlation between quantity and price changes. A positive correlation implies a demand curve shift and a negative correlation implies a supply curve shift. This test was performed both with prices lagged one period and unlagged for the years 1971-1979 in Table 12. With prices lagged one period, the simple correlation coefficient was 0.744 ; with prices unlagged the correlation coefficient was 0.560 . These results, in combination with casual inspection of the observed pattern of association between the index of domestic crop prices and domestic crop output (columns 4 and 1 of Table 12) strongly suggest that increases in domestic prices have generated increases in the domestic supply. The change between 1977-78 is the only exception, and it is generally acknowledged that this year was an unusually good weather year which undoubted1y accounts for most of the positive change. In summary government policy has done little to modernize and increase efficlency among agricultural producers (that is, cause an increase in supply to meet increases in demand). Hence it is now appropriate to consider the role of prices in influencing domestic food producers.

\section{The Role of Prices}

a) Food Crop Prices and Imports

The relative role of price incentives for domestic food crop farmers has not been well investigated or considered important by policymakers in the Jamaican setting. Output price policies may not always dominate performance, but ignoring product prices and their role in influencing the rate of return to agriculture can frequently lead to the 
failure of government programs designed to reduce structural constraints on agricultural production. Recent studies have demonstrated that inappropriate price policies can have a serious deleterious impact on efficiency and output in the agricultural sector.11/

We begin our investigation by analyzing the relationship between imported food prices and domestic food prices.12/ Under the assumption that Jamaica cannot influence world prices, there should exist a highly positive correlation between food import prices and domestic food prices. For the period 1970-1979, the simple correlation coefficient between food crop farmgate prices and imported food prices is . 16 , 1mplying a very weak relationship. However, after 1974, food imports become constrained in Jamaica due to balance of payments pressures and foreign exchange controls. Food imports were rationed at controlled prices, thus, import prices from 1975 to 1979 do not reflect the true scarcity value of food imports. This is also brought out by the fact that during 1970-1974 (a less constrained period) the simple correlation between domestic and imported food prices is 0.902 . This can also be seen by a quick inspection of columns 4 and 5 of Table 12. In short, in the early 1970's, there was a strong positive relationship between domestic farmgate prices and imported food prices. After 1974, food imports were constrained and rationed, leading to increases in domestic demand and higher domestic food prices as seen in the data in Table 12. This relationship is important since an overvalued exchange rate (reducing the costs of food imports below their true scarcity value) reduced the prices farmers could have received for domestic production before 1975. It has been shown that the exchange rate was overvalued 
between 10 to 20 percent during this period.13/ This implicit tax has not been adequately appreciated by Jamaican analysts discussing food policy. These results highlight the use of the exchange rate to mitigate cost of living increases in urban areas. This mechanism became a convenient means of indirect control of food prices in the early years of the Manley administration.

At the same time explicit retail price controls on selected food and dairy products also directly affected the rate of return to Jamaican producers. For example, Table 13 illustrates the fact that the real prices received by farmers for beef and milk have remained fairly constant over the period 1970-1978. Hence, little incentive had been given to these farmers to increase output or upgrade their operations. Beef prices were decontrolled in 1973. This permitted local supply and demand conditions to reemerge allowing farmgate prices to rise 23 percent in 1973 (column 1, Table 13). This partially compensated producers for the lack of any upward adjustment in the previous three years. However, at the same time, the government allowed beef imports to increase approximately 70 percent in 1973 (column 4, Table 13). This action clearly prevented any continuing rise in local beef prices. After 1973, substantial increases in beef imports was used as a mechanism to contain domestic beef prices, during the late 1970's, to a level well below local supply and demand conditions. The retail prices of livestock products have also been depressed and have followed the trend of farmgate prices. This pricing policy, which has benefited domestic consumers, may be the primary reason why farmers in the 1970's shifted 
out of livestock operations and into domestic crop and other activities as seen earlier in Table 2 .

b) Supply Elasticities

Having examined important elements conditioning price formation for domestic food producers, we can now turn to a formal analysis of the relationship between prices and output. This is done by estimating supply functions over the period 1971-1979.14/ The crop supply functions are of the form:

$$
Q_{t}=a_{0}+a_{1} P_{t-1}+\varepsilon_{t} \text {, }
$$

where $Q_{t}$ is the quantity Index of a given crop group; $P_{t-1}$ is the farmgate price index deflated by the implictt GDP deflator, lagged one year; $\varepsilon_{t}$ is the error term. For livestock, the supply functions relate the quantity of livestock product with the real farmgate price lagged one year.

The results of these supply functions are presented in Table 14. The estimated supply functions for domestic food crops are revealing. The aggregate food crop output-price relationship (shown in row one) is positive, significant and elastic (1.01). The high elasticity of supply for domestic food crops as a whole indicates that prices not only are necessary but very likely may also constitute a sufficient condition to generate large increases in supply. A $10 \%$ increase in price would induce a $10 \%$ increase in output. However, a qualification is in order. While the data for the 1970 s indicate a promising positive supply response, prices, in the long run, may not constitute a sufficient condition for substantial output increases if the increase in output has to be accompanied by a corresponding increase in acreage cultivated by 
domestic food crop farmers. Given the highly concentrated distribution of land, and the fact that small farmers comprise the majority of domestic producers, one wonders how much more land can be acquired or rented by these farmers in the rural setting of Jamaica. At the same time the absence of any effective efforts to promote more efficient small farmer technology in domestic food crop production has meant that the land constraint could not be relaxed by a sustained increase in yields. Yields in fact have remained stagnant during the 1970 s. Nevertheless, the data in Table 14 underscores the fact that those crop groups that have significant output-price relationships accounted for approximately 50 percent of domestic food crop output in 1972. These crop groups, consisting of vegetables, legumes, potatoes, and other tubers, are mostly grown for commercial purposes. The other major crop group is made up of yams, which accounted for 36 percent of domestic food crop output in 1972. The price-output relationship for this crop group is not significant. The principal reason for this result may be that a significant part of yam output is for home consumption, not for the commercial market. $15 /$ One should make allowances for the marketed portion of output, but the data do not permit this. The other crop groups accounted for only 14 percent of domestic crop output in 1972 with Plantains accounting for half of the "other" category. Prices do not seem to play a major role in determining the output of these other minor crop groups.

Supply functions of beef and milk were also estimated (rows 11 and 12). In these cases the output-price relationships were not significant. This is not surprising given the low variation and unchanging 
pattern of real prices over the decade of the 1970 's associated with explicit price controls and/or the indirect use of imports to control domestic prices discussed earlier.

The above findings can now be used to evaluate the influences of changes in real prices in determining the increases in domestic crop output. The real prices of domestic food crops before 1975 were depressed by the overvalued exchange rate and liberal food import policy. Hence, part of the low growth of this subsector in the early 1970 's can be explained by low product prices. After 1975, real farmgate prices were determined by increases in domestic demand which could not be satisfied through cheap food imports due to the more strict import control regime. These new conditions led to increases in domestic food crop prices which in turn led to increases in food crop output in the late 1970s, reflecting the price responsiveness of domestic crop farmers.

c) Demand Elasticities

The previous section confirms the importance of prices in stimulating a positive supply response particularly in a period of increased shortages and rationing of imported foodstuffs. However an interesting question arises concerning the degree to which domestic urban consumers will easily shift their consumption habits from imported foodstuffs to local products. Where there is a substitute or near substitute available (e.g. beef and dairy products) this is feasible and likely as long as the local cost of producing these local supplies is not prohibitive or can be reduced with technological research and investment. 
Where there are no close substitutes or consumer tastes are sharply different then the role of prices in promoting a shift in consumption habits is less certain. This would be the case in shifting urban consumption tastes from consuming imported wheat and other cereal products to the consumption of local tropical root crops, legumes, etc.

This dichotomy reflects the situation in Jamaica where middle class urban consumers have developed a taste for imported cereal crops that cannot be grown easily in a tropical setting. We examined the relationship between imports and domestic food output from the demand side. This was done by estimating CES demand functions to analyze consumers' choices between consuming imported food and domestic food. The demand function estimated was derived from a weakly separable utility function. Consumers were assumed to maximize utility by first allocating income between various groups of commodities and then deciding if the goods in these groups should be purchased from imported or domestic sources. The general form of the utility function utilized was of the CES family:

$$
V=\left[\delta_{1} e^{\lambda_{1} t_{1}} x_{M}^{-P}+\delta_{2} e^{\lambda_{2} t} x_{D}^{-e^{-1 / P}}\right.
$$

The underlying demand function $16 /$ then took the form of:

$$
\left(\frac{\mathrm{X}_{\mathrm{M}}}{\mathrm{X}_{\mathrm{D}}}\right)=\left(\frac{\delta_{1}}{\delta_{2}}\right)^{\sigma}\left(\frac{\mathrm{P}_{\mathrm{D}}}{\mathrm{P}_{\mathrm{M}}}\right)^{\sigma} \alpha \mathrm{FX} \mathrm{e}^{\mathrm{B} \text { POLITICAL }}+\left(\lambda_{2}-\lambda_{1}\right) \text { TIME }
$$

Where $X_{M}$ is imported food; $X_{D}$ is domestic food; $P_{M}$ is the price of imported food; $\mathrm{P}_{D}$ is the price of domestic food; $F X$ is foreign exchange avallable for imports; POLITICAL is a dummy variable where it equals 0 before 1972 and 1 after 1972 to capture the influence of a change in economic and food polictes between the JLP and PNP governments; TIME is 
included to capture whether or not there was a change in consumer preferences over this period; and $\sigma$ is the elasticity of substitution.

Equation 2 was estimated over the period 1965-1979 using ordinary least squares. For the initial estimation the Durbin-Watson statistic (d) was equal to 2.80 which left the results of the test for autocorrelation inconclusive. However, using a maximum likelihood technique to estimate Equation 2 improved the explanatory power of the model and the $\mathrm{D}-\mathrm{W}$ statistic was approximately 2 . The results $17 /$ of this estimation are as follows:

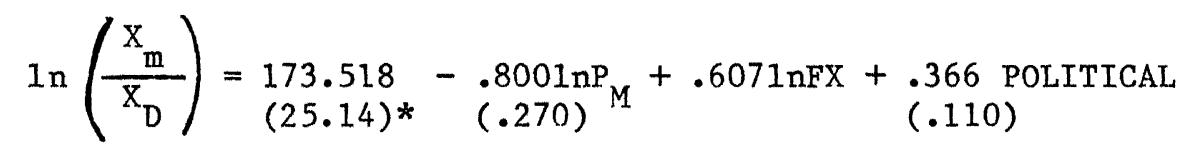

$$
\begin{aligned}
& -.089 \text { TIME } \\
& \mathrm{R}^{2}=.951 \\
& F=38.73 \\
& D-W=2.04
\end{aligned}
$$

The findings suggest the following: 1) the elasticity of substitution, $\sigma$, is equal to the coefficient on the price variable which is .80 . Thus, relative price changes have little impact on influencing consumer cholce of food consumption. Hence, a devaluation which would raise the price of imported food would not lead to a large increase in domestic food consumption as consumers would not switch to domestic food away from imported food. This is somewhat contradictory to the mainstream belief that a devaluation would lead to large shifts in consumer demand for domestic foodstuffs. 2) The ratio of imported food to domestic food is somewhat insensitive to the change in foreign exchange holdings. Decreases in foreign exchange do not influence switching by consumers to 
domestically produced food. 3) The coefficient of TIME is negative implying that tastes have changed towards domestic food and away from imported food. However this may be more a function of less food imports rather than a true switch by consumers. 4) The dummy variable, POLITICAL, is significant which suggests that there was a shift in the demand function and a change in the policy mix from the JLP to the PNP governments.

These results suggest that urban consumers in Jamaica will not change their food consumption habits lightly. Small price changes associated with temporary import constraints, devaluations and/or foreign exchange rationing will not lead to substantial changes in demand for local foodstuffs. However, substantial shortages and rationing can of course redirect consumption patterns as the previous evidence of the mid-to-late 1970s showed.

Furthermore if the government is determined to follow a successful long run import substitution pattern of food production, effort must be made to promote the production of those products (such as rice, dairy products and beef) for which there is a strong demand by urban consumers. Otherwise emphasis must be directed more towards export earnings to service non-substitutable food import demand.

\section{Conclusions and Implications}

The recent growth of domestic food output appears to have been influenced largely by market forces stimulating domestic demand. Structural and/or technical change played practically no role in this performance. Since 1965, both the JLP and PNP governments have undertaken subsidy assistance schemes designed to improve the rural 
infrastructure for domestic food crop producers. However, these subsidy programs have had only a limited impact on output and an equally 1imited distribution among domestic food producers. The PNP's policy of promoting food self-sufficiency in the late 1970's continued this pattern. Approximately 57 million Jamaican dollars were spent on collective food farms, land redistribution schemes and credit programs. Nevertheless these programs had minimal influence on production and the alleged credit schemes have, in fact, become merely one-shot income transfers to those farmers fortunate enough to receive the loans. In short, over the past twenty years, government policy has been concerned with programs focused on piecemeal and poorly administered efforts at structural change while ignoring the potential incentive effect of prevailing prices and pricing policy on domestic food producers.

This lack of concern for creating better pricing incentives, which could improve the rate of return to agriculture for all farmers, probably reflects the government's interest in allocating benefits to specific target groups or party members in rural areas. Patronage in the form of input subsidies is a far more attractive political vehicle and propaganda tool than policies designed to improve the functioning of markets. Moreover, price and exchange rate policies that improve price incentives for farmers may, in the short run, increase food prices in urban areas. This would have unfavorable political ramifications on important urban political constituencies. This is not to suggest that price policy favorable to farmers is a panacea for modernization and efficlency in agriculture. Clearly, technical change and structural reforms are important as we11. 
In particular, structural reforms and/or productivity increases may have to be more effectively introduced in the future to relax the land constralnt facing the large number of small domestic food producers. Similarly, new food product lines may have to recelve technological and financial support to more adequately satisfy urban consumer demand than does the current line of tropical products. However, the true lesson of the last fifteen years is that undue emphasis on piecemeal structural reforms and input subsidies accomplishes little in improving the rate of return to farming if product pricing incentives are absent or counterproductive.

More liberal price and exchange rate polictes could have made an important contribution towards improving the economic rate of return for domestic agricultural producers. However a less controlled market environment implies a less interventionist posture. Among other things this reduces the relative role of the government in dispensing political patronage and in mobilizing political constituencies. This was clearly an unattractive option for the populist Manley administration in the 1970s. State control and/or ownership in key activities was an overriding political goal. Emphasizing price incentives for private agricultural producers was not consistent with these political objectives. Nevertheless the net result of both the positive and the negative performance of domestic agriculture during this period was that the product pricing milieu (rather than structural reforms or short lived unsustainable input subsidy schemes) still prevailed as the dominant influence determining production decisions and output. 


\section{FOOTNOTES}

1. Alain de Janvry, The Agrarian Question and Reformism in Latin America, Johns Hopkins University Press, Baltimore, 1982.

2. G. Edward Schuh, "Approaches to 'Basic Needs' and to 'Equity' that Distort Incentives in Agriculture," in T. W. Schultz (ed.) Distortions of Agricultural Incentives, Indiana University Press, 1978.

3. On these points see Owen Jefferson, The Post-War Economic Development of Jamaica, Institute of Social and Economic Research, Kingston, Jamaica, 1972; and Car1 Stone, "Political Aspects of Postwar Agricultural Policies in Jamaica (1945-1970), Social and Economic Studies, Vo1. 23, 1974, pp. 145-175.

4. On this issue see Carl Stone, Democracy and Clientelism in Jamaica, Transaction Books, New Brunswick, N.J. and London, U.K., 1980.

5. This data is dependent on the accuracy of the extension agent and officials reporting both Land Lease data and general Ministry of Agriculture estimates of production.

6. For a discussion of the distortions in the rural financial markets of Jamaica during the 1970s see Douglas H. Graham and Compton Bourne, "Agricultural Credit and Rural Progress in Jamaica: A Development Dilemma" in Borrowers and Lenders edited by John Howe11, Overseas Development Institute, London, 1981; for a detailed review of the Crop Lien Program see Douglas H. Graham and Stephen Pollard, "The Crop Lien Program in Jamaica: Implications of a Credit Project Transformed into an Ad-Hoc Income Transfer Program," Social and Economic Studies (forthcoming).

7. This finding among many others came out of a detailed farm level survey of Crop Lien Program clients and reported on in "Farm Level Survey and Analysis of Selected Clients of the Crop Lien Program in St. Catherine, Jamaica," report to Ministry of Agriculture, Jamaica, April 1982, by Douglas H. Graham, Stephen Pollard and Compton Bourne.

8. J.K. Boyce and R.E. Evenson, "National and International Agricultural Research and Extension Programs," Agricultural Development Council, New York, 1975.

9. Reed Hertford and Andrew Schmitz, "Measuring Economic Returns to Agricultural Research," in Resource Allocation and Productivity in National and International Agricultural Research, edited by Thomas Arndt et al., University of Minnesota Press, 1977. 
10. Given these circumstances, classification of research by crop or function, a traditional measure of research output, was not undertaken here. For a review of the current organlzation and state of agricultural research in the Caribbean see L. B. Coke and P. I. Gomes, "Critical Analysis of Agricultural Research and Development Institutions and Their Activities," Social and Economic Studies, Vo1. 28, 1979, pp. 97-138.

11. On this issue see the studies by Lucio G. Reca, Argentina: Country Case Study of Agricultural Prices, Taxes and Subsidies, World Bank Staff Paper, No. 386, Apri1, 1980; William Cuddihy, Agricultural Price Management in Egypt, World Bank Staff Working Paper No. 388, March, 1980; C. Gotsch and G. Brown, Prices, Taxes and Subsidies in Pakistan Agriculture, 1960-1976, World Bank Staff Paper No. 387, Apri1, 1980; and Malcolm D. Bale and Ernst Lutz, "Price Distortions in Agriculture and Their Fffects: An International Comparison," American Journal of Agricultural Economics, Vo1. 63, 1981, pp. 8-22.

12. This relationship has been investigated in other countries with similar findings as noted for Jamaica (See: T. W. Schultz, "Value of U.S. Farm Surpluses to Underdeveloped Countries," Journal of Farm Economics, Vol. 42, 1960, pp. 1019-1030; Franklin M. Fisher, "A Theoretical Analysis of the Impact of Food Surplus Disposal on Agricultural Production in Recipient Countries," Journal of Farm Economics, Vo1. 45, 1963, pp. 863-875; and Reed Hertford, "Government Price Policies in Colombia," in T. W. Schultz (ed.), op. cit.).

13. On the poor performance of agricultural exports during this period and the severe implicit taxation of agricultural exports carried out by the government's marketing boards and an overvalued exchange rate see Stephen Pollard and Douglas Graham, "Price Policy and Agricultural Export Performance in Jamaica," paper presented at the annual meeting of the American Agricultural Economics Association, Logan, Utah, 1982.

14. For a review of supply functions used in LDC settings see Hossein Askari and John T. Cummings, Agricultural Supply Response - A Survey of the Econometric Evidence. Praeger Publishers, New York, 1976.

15. This was found to be the case from field surveys undertaken by the authors in St. Elizabeth and St. Catherine parishes in Jamaica.

16. The derivation of the underlying demand functions is from R.G. Gregory, "Un1ted States Imports and Internal Pressure of Demand: 1948-68," The American Economic Review, Vo1. 61, 1971, pp. 28-47. We modified this function to account for foreign exchange influences as well as political interaction between government and consumers over this period. 
17. Data for the domestic price variable $P_{D}$ was not available over the entire time period 1965-79. Hence estimates of $\delta_{1}, \delta_{2}$, cannot be derived. However the expected sign of $\sigma$, the coefficient for $1_{M} P_{M}$, is negative and the estimation supported this. 
Table 1. Real Rates of Growth of the Economy, the Nonagricultural Sector, the Manufacturing Sector, the Mining Sector and the Agricultural Sector in Jamaica, 1961-1979al

\begin{tabular}{|c|c|c|c|c|c|c|c|c|}
\hline Periodb/ & $\begin{array}{c}\text { National } \\
\text { GDP }\end{array}$ & $\begin{array}{l}\text { Non-Agr. } \\
\text { GDP }\end{array}$ & $\begin{array}{c}\text { Manufacturing } \\
\text { GDP }\end{array}$ & $\begin{array}{l}\text { Mining } \\
\text { GDP }\end{array}$ & $\begin{array}{l}\text { Agr. } \\
\text { GDP }\end{array}$ & $\begin{array}{l}\text { Export Agr. } \\
\text { GDP }\end{array}$ & $\begin{array}{l}\text { Domestic Food } \\
\text { Crop GDP }\end{array}$ & $\begin{array}{c}\text { Livestock } \\
\text { GDP }\end{array}$ \\
\hline & (1) & (1) & (3) & (4) & $(5)$ & $(6)$ & $(7)$ & $(8)$ \\
\hline $1962-1967$ & 5.44 & 5.62 & 6.10 & 5.77 & 2.13 & 1.19 & 1.56 & 6.71 \\
\hline $1967-1972$ & 6.28 & 6.87 & 4.67 & 13.30 & 1.92 & -3.14 & 6.78 & 0.39 \\
\hline $1972-1979$ & -1.51 & -1.67 & -2.67 & -1.05 & 1.12 & $-4 \cdot 20$ & 3.21 & 1.96 \\
\hline 1961-1979 & 2.81 & 3.08 & 2.28 & 5.26 & 1.70 & -2.11 & 3.54 & 3.03 \\
\hline
\end{tabular}

a/ Average annual compounded real rate of growth.

b/ Based on 5 year moving averages, for beginning and end points for the years indicated in the table.

Source: Growth rates derived from official national income and product data in National Income and Product, Department of Statistics, Government of Jamaica, Kingston, various years. 
Table 2. Percentage Distribution of Farms by Main Source of Farm Incomes, $1961,1968,1978$

\begin{tabular}{|c|c|c|c|c|c|c|c|c|c|}
\hline \multirow[b]{2}{*}{ Farm Size (acres) } & \multicolumn{3}{|c|}{ Export Crops } & \multicolumn{3}{|c|}{ Domestic Crops $1 /$} & \multicolumn{3}{|c|}{ Livestock } \\
\hline & 1961 & 1968 & 1978 & 1961 & 1968 & 1978 & 1961 & 1968 & 1978 \\
\hline $0<5$ & 52.0 & 36.3 & 29.6 & 44.4 & 45.1 & 64.9 & 3.6 & 13.4 & 5.5 \\
\hline $5<25$ & 61.5 & 51.2 & 43.6 & 32.1 & 37.0 & 50.3 & 6.4 & 8.6 & 6.1 \\
\hline $25<100$ & 58.7 & 45.7 & 38.4 & 21.7 & 27.6 & 37.6 & 19.6 & 22.7 & 24.0 \\
\hline 100 and above & 62.3 & 50.8 & 41.5 & 6.8 & 7.8 & 21.6 & 30.9 & 34.4 & 36.9 \\
\hline A11 Farms & 54.7 & 39.7 & 32.2 & 40.4 & 42.9 & 61.7 & 4.9 & 12.7 & 6.1 \\
\hline
\end{tabular}

1/ Includes Domestic as well as mixed crops.

Source: Agricultura1 Census 1961/62, Tables 12-16, pp. 11-15; Agricultura1 Census 1968/69, Volume III, Table 34, pp. 26-27; Agricultural Census 1978/79. 
Table 3. Percentage Distribution of Single Holders $1 /$ by Principal Livelihood

\begin{tabular}{|c|c|c|c|c|c|c|c|c|}
\hline \multirow[b]{2}{*}{ Farm Size (acres) } & \multicolumn{2}{|c|}{ Farming $2 /$} & \multicolumn{2}{|c|}{$\begin{array}{l}\text { Agricultural } \\
\text { Employment }\end{array}$} & \multicolumn{2}{|c|}{$\begin{array}{l}\text { Non-Agri. } \\
\text { Employment }\end{array}$} & \multicolumn{2}{|c|}{ Other } \\
\hline & 1968 & 1978 & 1.968 & 1978 & 1968 & 1978 & 1968 & 1978 \\
\hline $0<5$ & 63.3 & 70.0 & 12.1 & 4.7 & 24.5 & 17.2 & 0.1 & 8.1 \\
\hline $5<25$ & 86.3 & 86.0 & 3.4 & 2.3 & 10.2 & 8.3 & 0.1 & 3.4 \\
\hline $25<100$ & 80.9 & 78.3 & 3.3 & 2.5 & 15.5 & 13.0 & 0.2 & 6.2 \\
\hline 100 and above & 66.2 & 67.0 & 3.5 & 3.6 & 29.8 & 22.0 & 0.4 & 7.5 \\
\hline Al1 Farms & 68.1 & 72.7 & 10.2 & 4.3 & 21.5 & 15.7 & 0.2 & 7.3 \\
\hline
\end{tabular}

1/ Single holders comprised 99 percent of all farm owners, but had only $68.6 \%$ of all acreage in 1968 and $62.2 \%$ of all acreage in 1978 .

2/ Includes both full and part-time farming.

Source: Same as Table 2. 
Table 4. Number of Farms in Jamaica by Size Groups for Selected Years

\begin{tabular}{|c|c|c|c|c|c|}
\hline Year & $\begin{array}{l}\text { Total } \\
\text { Number }\end{array}$ & $\begin{array}{c}\text { Under } \\
5 \text { Acres } \\
\end{array}$ & $\begin{array}{l}5 \text { Acres } \\
\text { to under } \\
25 \text { Acres }\end{array}$ & $\begin{array}{l}25 \text { Acres } \\
\text { to under } \\
100 \text { Acres }\end{array}$ & $\begin{array}{l}100 \text { Acres } \\
\text { and Over }\end{array}$ \\
\hline 1954 & $\begin{array}{c}198,883 \\
(100 \%) 1 /\end{array}$ & $\begin{array}{l}139,043 \\
(69.91)\end{array}$ & $\begin{array}{r}53,024 \\
(26.66)\end{array}$ & $\begin{array}{r}5,603 \\
(2.82)\end{array}$ & $\begin{array}{l}1,213 \\
(.61)\end{array}$ \\
\hline 1961 & $\begin{array}{r}158,577 \\
(100 \%)\end{array}$ & $\begin{array}{l}112,626 \\
(71.02)\end{array}$ & $\begin{array}{c}41,053 \\
(25.89)\end{array}$ & $\begin{array}{r}3,785 \\
(2.39)\end{array}$ & $\begin{array}{l}1,113 \\
(.70)\end{array}$ \\
\hline 1968 & $\begin{array}{r}193,359 \\
(100 \%)\end{array}$ & $\begin{array}{l}151,705 \\
(78.46)\end{array}$ & $\begin{array}{r}37,607 \\
(19.45)\end{array}$ & $\begin{array}{r}3,055 \\
(1.58)\end{array}$ & $\begin{array}{r}992 \\
(.51)\end{array}$ \\
\hline 1978 & $\begin{array}{r}183,988 \\
(100 \%)\end{array}$ & $\begin{array}{l}150,633 \\
(81.87)\end{array}$ & $\begin{array}{c}29,839 \\
(16.20)\end{array}$ & $\begin{array}{r}2,400 \\
(1.30)\end{array}$ & $\begin{array}{c}1,116 \\
(0.60)\end{array}$ \\
\hline
\end{tabular}

1/ Percentages are Row Percentages.

Source: Agricultural Census 1968/69, Volume IA, p. 19, Agricultural Census 1978/79. 
Table 5. Total Acreage of Land in the Agricultural Sector in Jamaica by Size Groups for Selected Years.

\begin{tabular}{|c|c|c|c|c|c|}
\hline Year & $\begin{array}{c}\text { Total } \\
\text { Acreage }\end{array}$ & $\begin{array}{c}\text { Under } \\
5 \text { Acres } \\
\end{array}$ & $\begin{array}{l}5 \text { Acres } \\
\text { to Under } \\
25 \text { Acres }\end{array}$ & $\begin{array}{l}25 \text { Acres } \\
\text { to Under } \\
100 \text { Acres }\end{array}$ & $\begin{array}{l}100 \text { Acres } \\
\text { and Over }\end{array}$ \\
\hline 1954 & $\begin{array}{c}1,914,375 \\
(100 \%) 1 /\end{array}$ & $\begin{array}{l}249,074 \\
(13.01)\end{array}$ & $\begin{array}{l}502,924 \\
(26.27)\end{array}$ & $\begin{array}{l}232,178 \\
(12.13)\end{array}$ & $\begin{array}{l}930,195 \\
(48.59)\end{array}$ \\
\hline 1961 & $\begin{array}{c}1,711,430 \\
(100 \%)\end{array}$ & $\begin{array}{l}198,000 \\
(11.57)\end{array}$ & $\begin{array}{l}389,441 \\
(22.76)\end{array}$ & $\begin{array}{r}167,607 \\
(9.79)\end{array}$ & $\begin{array}{l}956,382 \\
(55.88)\end{array}$ \\
\hline 1968 & $\begin{array}{c}1,489,188 \\
(100 \%)\end{array}$ & $\begin{array}{l}229,216 \\
(15.39)\end{array}$ & $\begin{array}{l}340,757 \\
(22.88)\end{array}$ & $\begin{array}{r}127,28 \\
(8.54)\end{array}$ & $\begin{array}{l}792,007 \\
(53.15)\end{array}$ \\
\hline 1978 & $\begin{array}{c}1,327,045 \\
(100 \%)\end{array}$ & $\begin{array}{l}216,679 \\
(16.02)\end{array}$ & $\begin{array}{l}255,841 \\
(19.28)\end{array}$ & $\begin{array}{r}107,216 \\
(8.08)\end{array}$ & $\begin{array}{l}751,309 \\
(56.62)\end{array}$ \\
\hline
\end{tabular}

1/ Percentages are Row Percentages

Source: Agricultural Census 1968/69, Volume IA, p. 20, Agricultural Census 1978/79. 
Table 6. Total Expenditure on Major Agricultural Subsidy Programs in Jamaica, 1964-1979

\begin{tabular}{lcc}
\hline Year & $\begin{array}{c}\text { Total Expenditure } \\
\text { on Subsidies }\end{array}(000 \$)$ & $\begin{array}{c}\text { Percent of } \\
\text { Farmers Reached }\end{array}$ \\
\hline 1964 & $\$ 1,220$ & $1.0 \%$ \\
1965 & 1,637 & 2.3 \\
1966 & 2,390 & 5.4 \\
1967 & 2,736 & 5.4 \\
1968 & 1,004 & 4.2 \\
1969 & 974 & 5.3 \\
1970 & 1,170 & 6.5 \\
1971 & 1,629 & 10.8 \\
1972 & 1,091 & n.a. \\
1973 & 968 & n.a. \\
1974 & 1,082 & n.a. \\
1975 & 2,253 & n.a. \\
1976 & 2,959 & n.a \\
1977 & 2,128 & n.a. \\
1978 & 1,143 & n.a. \\
1979 & 1,737 & \\
\hline & & \\
\hline
\end{tabular}

1/ 1974 constant dollars source: Unpublished Data, Ministry of Agriculture. 
Table 7. Average Fertilizer Subsidy and Distribution of Subsidy in Jamaica, 1967-1979

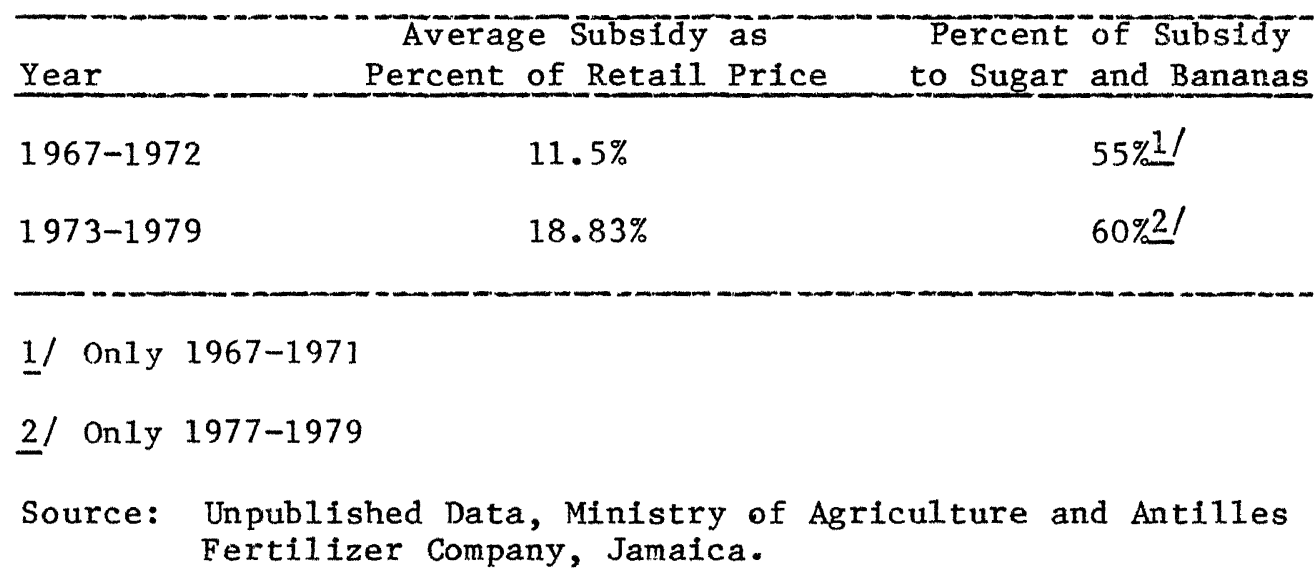


Table 8. Jamaican Government Expenditure, Output, Acreage and Number of Farmers Placed in the Land Lease Program

\begin{tabular}{|c|c|c|c|c|c|c|c|c|}
\hline Year & $\begin{array}{c}\text { Number } \\
\text { of } \\
\text { Tenants }\end{array}$ & $\begin{array}{l}\text { Total } \\
\text { Acres } \\
\text { Leased }\end{array}$ & $\begin{array}{l}\text { Total } \\
\text { Arable } \\
\text { Acres } \\
\end{array}$ & $\begin{array}{c}\text { Total } \\
\text { Acres } \\
\text { Planted } \\
\end{array}$ & $\begin{array}{c}\text { tal Domest } \\
\text { Foodcrops } \\
\text { Produced } \\
\text { (in Tons) } \\
\end{array}$ & $\begin{array}{l}\text { Total } \\
\text { Costs } 1 / \\
(\$)\end{array}$ & $\begin{array}{l}\text { Tota1 } \\
\text { Loans } 1 / \\
(\$)\end{array}$ & $\begin{array}{l}\text { Total Loans } \\
\text { Recovered 1/ } \\
(\$)\end{array}$ \\
\hline $\begin{array}{l}1973 \\
1974\end{array}$ & $\begin{array}{l}3,082 \\
9,022\end{array}$ & $\begin{array}{l}24,205 \\
33,593\end{array}$ & $\begin{array}{l}14,256 \\
17,405\end{array}$ & $\begin{array}{r}3,565 \\
12,330\end{array}$ & $\begin{array}{r}714 \\
8.382\end{array}$ & $\$ \quad 840,836$ & $\begin{array}{l}\$ 62,802 \\
\quad 985,960\end{array}$ & $\$ 12,021$ \\
\hline $\begin{array}{l}1975 \frac{2 /}{1} \\
1976 \text { I } \\
1977 \\
1978 \\
1979\end{array}$ & $\begin{array}{r}12,193 \\
12,193 \\
9,905 \\
2,019 \\
804\end{array}$ & $\begin{array}{r}29,132 \\
29,132 \\
24,684 \\
4,108 \\
875\end{array}$ & $\begin{array}{r}17,735 \\
17,735 \\
13,243 \\
2,896 \\
374\end{array}$ & $\begin{array}{l}38,907 \\
38,907 \\
26,275 \\
22,033 \\
24,117\end{array}$ & $\begin{array}{l}55,819 \\
55,819 \\
31,498 \\
59,316 \\
79,056\end{array}$ & $\begin{array}{l}6,822,236 \\
5,116,485 \\
3,983,101 \\
2,687,937 \\
2,653,706\end{array}$ & $\begin{array}{r}2,562,118 \\
1,581,044 \\
1,788,327 \\
1,119,165 \\
832,371\end{array}$ & $\begin{array}{l}328,517 \\
299,659 \\
318,538 \\
271,575 \\
212,042\end{array}$ \\
\hline TOTAL & 37,025 & 116,597 & 65,909 & 127,227 & 234,785 & $24,887,966$ & $9,331,807$ & $1,623,378$ \\
\hline
\end{tabular}

Source: Unpublished data from the Production Unit, Ministry of Agriculture.

1/ In 1974 constant Jamaican dollars.

2/ Annual Data not available for 1975 and 1976; however cumulative program data to date was available in 1977 and 1974 to allow us to derive the approximations for 1975 and 1976 . The sum was divided equally between the two years. 
Table 9. Jamaican Government Expenditure, Output and Number of Loans in the Crop Lien Loan Program, 1977-79.

\begin{tabular}{|c|c|c|c|c|c|c|}
\hline Year & $\begin{array}{l}\text { Number } \\
\text { of Crop } \\
\text { Lien } \\
\text { Farmers }\end{array}$ & $\begin{array}{l}\text { Tota1 } \\
\text { Loans } \\
\text { Granted } 1 /\end{array}$ & $\begin{array}{c}\text { Average } \\
\text { Loan }\end{array}$ & $\begin{array}{c}\text { Tons } \\
\text { Produced }\end{array}$ & $\begin{array}{l}\text { \$ Loan } \\
\text { per Ton }\end{array}$ & $\begin{array}{l}\% \text { of } \\
\text { Total } \\
\text { Output }\end{array}$ \\
\hline $\begin{array}{l}1977 \\
1978 \\
1979\end{array}$ & $\begin{array}{r}32,283 \\
6,259 \\
5,447\end{array}$ & $\begin{array}{l}8,316,290 \\
2,477,988 \\
1,942,193\end{array}$ & $\begin{array}{l}\$ 257 \\
\$ 396 \\
\$ 357\end{array}$ & $\begin{array}{l}14,716 \\
41,123 \\
20,512\end{array}$ & $\begin{array}{r}\$ 565 \\
60 \\
95\end{array}$ & $\begin{array}{l}3.2 \% \\
7.3 \\
4.4\end{array}$ \\
\hline TOTAL & 43,989 & $12,736,471$ & $\$ 289$ & 76,351 & $\$ 166.8$ & 5.1 \\
\hline
\end{tabular}

Source: Unpublished data from the Production Unit, Ministry of Agriculture.

1/ In 1974 constant Jamaican dollars. 
Tab1e 10. Expenditure on Research and Extension on Domestic Food Crops and Livestock in Jamaica, 1965-19791

Panel A. Domestic Food Crops

\begin{tabular}{|c|c|c|c|c|}
\hline Fiscal Years & $\begin{array}{l}\text { Cumulative } \\
\text { Total Expenditure in } \\
\text { Domestic Crop Research }\end{array}$ & $\begin{array}{l}\text { Domestic Crop Res. } \\
\text { as \% Domestic } \\
\text { Crop GDP }\end{array}$ & $\begin{array}{l}\quad \text { Cumulative } \\
\text { Expenditure in } \\
\text { Domestic Food } \\
\text { Crop Extension } \\
\end{array}$ & $\begin{array}{l}\text { Domestic Foodcrop } \\
\text { Extension as \% } \\
\text { Domestic Crop GDP } \\
\end{array}$ \\
\hline $1964-1972$ & \$J. 7.8 & $1.64 \%$ & \$J. 13.0 & $6.78 \%$ \\
\hline $1973-1979$ & 6.7 & 1.28 & 31.5 & 6.01 \\
\hline
\end{tabular}

$\underline{\text { Pane1 B. }}$ Livestock

\begin{tabular}{|c|c|c|c|c|c|}
\hline Fiscal Years & In & $\begin{array}{l}\text { Cumulative } \\
\text { Total Expenditure } \\
\text { Livestock Research }\end{array}$ & $\begin{array}{l}\text { Livestock Res, as } \\
\% \text { Livestock GDP }\end{array}$ & $\begin{array}{l}\text { Cumulative } \\
\text { Expenditure } \\
\text { in Livestock } \\
\text { Development } \\
\text { and Extension }\end{array}$ & $\begin{array}{c}\text { Livestock Exten. } \\
\text { Exp. as \% } \\
\text { Livestock GDP }\end{array}$ \\
\hline $1964-1972$ & & \$J. 4.98 & 1.69 & \$J. 14.0 & 4.56 \\
\hline $1973-1979$ & & 9.1 & 2.83 & 19.2 & 6.1 \\
\hline
\end{tabular}

1/ In $(1,000,000) 1974$ constant J. dollars

Source: Estimates of Government Expenditure, Government of Jamaica, various years. 
Table 11. Value of Purchases, Operating Deficit, and Subsidies Received by the Agriculturai Marketing Corporation (AMC) 1964-1979

\begin{tabular}{llccc}
\hline Years & $\begin{array}{c}\text { Total Value } \\
\text { of Purchases }\end{array}$ & $\begin{array}{c}\text { Total } \\
\text { Deficit }\end{array}$ & $\begin{array}{c}\text { Total Government } \\
\text { Study }\end{array}$ & $\begin{array}{c}\text { Percentage of Total } \\
\text { Output Marketed }\end{array}$ \\
$1964-1971$ & $24,307,000$ & $12,873,000$ & $10,541,000$ & $12 \%$ \\
$1972-1979$ & $30,328,0001 /$ & $16,048,0001 /$ & $21,623,000$ & $6 \%$ \\
\hline
\end{tabular}

1/ Nominal values for the years 1975-1978 only

Source: Unpublished Data from the AMC and Estimates of Government Expenditure, Government of Jamaica, various years. 
Table 12. Indices of Domestic Food Quantities and Prices in Jamaica, 1969-1979

\begin{tabular}{lccccc}
\hline & $\begin{array}{c}\text { Index of } \\
\text { Domestic } \\
\text { Crop Output } \\
(1)\end{array}$ & $\begin{array}{c}\text { Index of } \\
\text { Domestic } \\
\text { Crop } \\
\text { Yields }\end{array}$ & $\begin{array}{c}\text { Index of } \\
\text { Food } \\
\text { Imports } \\
\text { Year }\end{array}$ & $\begin{array}{c}\text { Index of } \\
\text { Domestic } \\
\text { Crop Prices }\end{array}$ & $\begin{array}{c}\text { Index of } \\
\text { Food Import } \\
\text { Prices } \\
(5)\end{array}$ \\
\hline 1969 & n.a & n.a. & 119.8 & n.a. & 70.7 \\
1970 & 68.4 & 100.0 & 90.3 & 74.0 & 68.3 \\
1971 & 92.9 & 108.0 & 90.1 & 85.7 & 89.0 \\
1972 & 101.8 & 105.0 & 101.8 & 86.1 & 76.7 \\
1973 & 93.4 & 108.0 & 88.8 & 97.7 & 89.0 \\
1974 & 100.0 & 109.0 & 100.0 & 100.0 & 100.0 \\
1975 & 100.0 & 115.0 & 101.8 & 104.2 & 83.8 \\
1976 & 99.9 & 107.0 & 101.3 & 101.1 & 77.8 \\
1977 & 122.2 & 117.0 & 79.2 & 122.3 & 79.4 \\
1978 & 155.1 & 122.0 & 107.3 & 95.7 & 103.1 \\
1979 & 132.8 & 26.0 & n.a. & 109.0 & \\
\hline
\end{tabular}

Sources: Indices of Domestic Agricultural Production and Farmgate Price (1970-1979), Data Bank and Evaluation Division, Ministry of Agriculture, Jamaica, and Statistical Yearbook of Jamaica, 1979, Department of Statistics, Jamaica. 
Table 13. Annual Farmgate Prices, Retail Prices, Output and Imports of Beef and Milk in Jamaica 1970-1979

\begin{tabular}{|c|c|c|c|c|c|c|c|c|}
\hline \multirow[b]{2}{*}{ Year } & \multicolumn{4}{|c|}{ Beef } & \multicolumn{4}{|c|}{ Milk } \\
\hline & $\begin{array}{l}\text { Farm } \\
\text { Price1/,2/ } \\
(1)\end{array}$ & $\begin{array}{l}\text { Retail } \\
\text { Price } 1 / \\
(\$ / 1 b) \\
(2)\end{array}$ & $\begin{array}{c}\text { Output } \\
\text { ('000 1bs) } \\
\text { (3) }\end{array}$ & $\begin{array}{c}\text { Imports } \\
(\text { '000 Ibs) } \\
\text { (4) }\end{array}$ & $\begin{array}{l}\text { Farm } \\
\text { Price } 1 / \\
(\notin / q t) \\
(5)\end{array}$ & $\begin{array}{l}\text { Retail } \\
\text { Price } 1 / \\
(c / q t) \\
(6)\end{array}$ & $\begin{array}{c}\text { Output } 3 / \\
(7)\end{array}$ & $\begin{array}{c}\text { Imports } \\
(\text { '000 1bs) } \\
(8)\end{array}$ \\
\hline $\begin{array}{l}1970 \\
1971\end{array}$ & $\begin{array}{r}\$ 35.6 \\
35.7\end{array}$ & $\begin{array}{l}1.09 \\
1.17\end{array}$ & $\begin{array}{l}27,400 \\
25,775\end{array}$ & $\begin{array}{l}9,067 \\
7,170\end{array}$ & $\begin{array}{l}23.3 \\
21.8\end{array}$ & $\begin{array}{l}37 \\
36\end{array}$ & $\underset{42}{\mathrm{n} . \mathrm{a}}$ & $\begin{array}{l}21,715 \\
20,377\end{array}$ \\
\hline 1972 & 35.1 & 1.18 & 27,117 & 3,350 & 27.2 & 39 & 41 & 28,013 \\
\hline 1973 & 43.5 & 1.38 & 29,063 & 9,671 & 26.5 & 36 & 41 & 14,235 \\
\hline 1974 & 42.5 & 1.32 & 28,128 & 8,671 & 25.0 & 32 & 43 & 32,827 \\
\hline 1975 & 43.4 & 1.34 & 31,169 & 11,058 & 26.5 & 32 & 43 & 17,529 \\
\hline 1976 & 41.9 & 1.28 & 27,212 & 11,044 & 23.7 & 30 & 42 & 27,300 \\
\hline 1977 & 40.7 & 1.20 & 27,233 & 10,947 & 21.2 & 27 & 41 & 20,297 \\
\hline 1978 & 43.4 & 1.24 & 25,574 & 9,493 & 24.5 & 29 & 43 & 27,401 \\
\hline 1979 & 47.9 & 1.56 & 25,177 & 17,674 & 26.0 & 37 & 40 & 24,165 \\
\hline
\end{tabular}

Source: Annual Reports of the Jamaica Livestock Association, various years; Social and Economic Surveys, various years; External Trade, various years; and $\overline{\text { Statistical }}$ Yearbook of Jamaica, 1979.

1/ Price is deflated by GDP deflator, base year 1974 .

2/ Farmgate Price for beef is per 100 pounds live weight.

3/ Milk output is Ministry of Agriculture estimate. 
Table 14. Estimates of Supply Functions for Selected Domestic Food Groups in Jamaica 1971-1979

\begin{tabular}{|c|c|c|c|c|}
\hline Food Group & Intercept & Price & $\mathrm{R}^{2}$ & $\begin{array}{l}\text { Short Run } \\
\text { rlasticity }\end{array}$ \\
\hline 1. Domestic Food & $\begin{array}{l}-0.748^{2 /} \\
(37.37) 1 /\end{array}$ & $\begin{array}{c}0.9812 / \\
(0.331) 1 /\end{array}$ & $\begin{array}{c}0.556^{2 /} \\
(10.02) \underline{1}\end{array}$ & 1.01 \\
\hline 2. Legumes & $\begin{array}{l}6.5012 / \\
(28.24)\end{array}$ & $\frac{0.2312 /}{(0.176)}$ & $\begin{array}{l}0.198^{2 /} \\
(1.98)\end{array}$ & 0.346 \\
\hline 3. Vegetables & $\begin{array}{r}-79.4221 \\
(36.55)\end{array}$ & $\frac{1.76221}{(0.326)}$ & $\begin{array}{l}0.807 \frac{21}{} \\
(33.45)\end{array}$ & 1.65 \\
\hline 4. Condiments & $\begin{array}{l}67.80 \\
(83.89)\end{array}$ & $\begin{array}{c}0.801 \\
(0.956)\end{array}$ & $\begin{array}{l}0.091 \\
(0.79)\end{array}$ & n.a. \\
\hline 5. Fruit & $\begin{array}{l}93.43 \\
(75.47)\end{array}$ & $\begin{array}{c}0.072 \\
(0.723)\end{array}$ & $\begin{array}{l}0.002 \\
(0.02)\end{array}$ & n.a. \\
\hline 6. Cereal & $\begin{array}{l}176.03 \\
(58.63)\end{array}$ & $\begin{array}{c}0.067 \\
(0.566)\end{array}$ & $\begin{array}{l}0.002 \\
(0.02)\end{array}$ & n.a. \\
\hline 7. Plantains & $\begin{array}{c}103.99 \\
(21.02)\end{array}$ & $\begin{array}{l}-0.20 \\
(0.287)\end{array}$ & $\begin{array}{l}0.067 \\
(0.57)\end{array}$ & n.a. \\
\hline 8. Potatoes & $\begin{array}{l}11.0921 \\
(44.72)\end{array}$ & $\frac{0.648^{2 /}}{(0.331)}$ & $\begin{array}{l}0.35421 \\
(4.38)\end{array}$ & 0.886 \\
\hline 9. Yams & $\begin{array}{l}75.55 \\
(32.67)\end{array}$ & $\begin{array}{c}0.277 \\
(0.291)\end{array}$ & $\begin{array}{l}0.114 \\
(1.04)\end{array}$ & n.a. \\
\hline 10. Other Tubers & $\begin{array}{l}14.77 \frac{21}{} \\
(41.51)\end{array}$ & $\begin{array}{l}0.940^{2 /} \\
(0.415)\end{array}$ & $\begin{array}{l}0.423^{21} \\
(5.86)\end{array}$ & 0.863 \\
\hline 11. Beef & $\begin{array}{l}26,625.6 \\
(7,461.8)\end{array}$ & $\begin{array}{c}18.78 \\
(184.3)\end{array}$ & $\begin{array}{l}0.01 \\
(0.08)\end{array}$ & $\mathrm{n} \cdot \mathrm{a}$. \\
\hline 12. Fresh Milk & $\begin{array}{c}7,449,952 \\
(13,604,360)\end{array}$ & $\begin{array}{l}101,109 \\
(547,100.1)\end{array}$ & $\begin{array}{l}0.005 \\
(0.04)\end{array}$ & n.a. \\
\hline
\end{tabular}

1/ Numbers in parentheses for the intercept and price varlables are the standard errors; for the $R^{2}$, it is the F-Statistic for the regression.

2/ Significant at the 5 percent level. 